
${ }^{35}$ Delay, J., and Buisson, J. F., J. Clin. Exp. Psychopath., No. 2,
Supp. 1, 51 (1958).

${ }^{36}$ West, E. D., and Dally, P. J., Brit. Med. J., i, 1491 (1959).

${ }^{37}$ Zeller, E. A., Barsky, T., Fonts, J. R., Kircheimer, W. A., and van Orden, L. S., Experientia, 8, 349 (1952).

${ }^{38}$ Undenfreund, S., Weissbach, F., and Bogdanski, D. F., J. Pharm. Exp. Ther., 120, 255 (1957).

${ }^{30}$ Rees, L., and Benaim, S., in "Neuropsychopharmacology" (Elsevier, Amsterdam, 1959).

${ }^{10}$ Rees, L., and Benaim, S., J. Ment. Sci. (in the press).

${ }^{41}$ Benaim, S., and Dixon, M. F., Brit. Med. J., ii, 1068 (1958). ${ }^{+2}$ De Verteuil, R. L., and Lehmann, H. E., Canad. Med. Assoc. J., 78,
131 (1958).

${ }^{43}$ Fisher, J. D., and Olver, M. F., Brit. Med. J., ii, 1225 (1958).

44 Pare, C. M. B., and Sandler, M., Lancet, i, 262 (1959).

${ }^{4} 5$ Smarr, E. R., Wolf, H., and Pressman, M. D., Amer. J. Psychiat., 114, 1115 (1958).

${ }^{46}$ Weiss, L, B., Davidson, J. H., Winsten, S., and Brody, H., J. Albert Einstein Med. Center, 6, 229 (1958).

${ }^{4}$ Zetzel, L., and Kaplan, H., New England J. Med., 258, 1209 (1958).

${ }^{48}$ Frantz, J. Amer. Med. Assoc., 167, 987 (1958).

49 Shay, H., and Sun, D. C. H., Ann. Int. Med., 49, 1246 (1958).

so Thal, N., Dis. Nerv. Syst., 22, 197 (1959).

"s Sainz, A., "The Phrenopraxic Activity of Nonnoxious Antidepressant", presented at a Conference on Amide Oxidase Inhibitors, New York Academy of Sciences (November 20-22, 1958).

3: Goldman, D., “Clinical Experiences with New Anti-depressant Drugs and Some Related Electro-Encephalographic Observa(unpublished results, 1958). ss Furst, W., Amer. S. Psychiat. (1960).

s4 Saunders, J. C. (in the press).

${ }^{6}$ Rees, L., and Davies, B. (to be published).

Dewhurst, W. G., and Pare, C. M. B., Symposium on Depression, Cambridge (September 1959).

${ }^{37}$ Feldstein, A., Hoagland, H., and Freeman, H., Science, 130, 500 (1959).

${ }^{58}$ Sigg, E. B., Canad. Psychiat. Assoc. J., 4, 75, Spec. Supp.

s Van Meter, W. G., Owens, H. T., and Himwich, H. E., Canal. Psychiat. Assoc. J., 4, 113, Spec. Supp. (1959)

${ }^{60}$ Kuhn, R., Schweiz. Med. Wschr., 88, 763 (1957)

${ }^{61}$ Kielholtz, P., and Battegay, R., Schw. Med. Wschr., 88, 736 (1958).

${ }^{62}$ Lehmann, H. E., Kahn, C. Ir., and de Verteuil, R. L., Canad. Psychiat. Assoc. J., 3, 155 (1958).

${ }^{63}$ Fazio, C., Gilberti, F., and Loeb, C., Minerva Med. (Torino), 49, 3143 (1958).

${ }^{64}$ Azima, H., and Vispo, R. H., Amer. J. Psychiat., 115, 245 (1958).

6s Saucier, J., and Dumas, C. F., Canad. Psychiat. Assoc. J., 4, 148 (1959).

${ }^{66}$ Hoff, H., Canad. Psychiat. Assoc. J., 4, Spec. Supp., 55 (1959).

${ }^{67}$ Delay, J., and Deniker, P., Canad. Psychiat. Assoc. J., 4, 100 , Spec. Supp. (1959).

${ }^{68}$ Rees, L., Brown, and Benaim, S. (to be published).

${ }^{89}$ Ball, J. R. B., and Kiloh, L. G., Brit. Med. J., ii, 1052 (1959)

${ }^{70}$ Rees, L., and Lambert, O., J. Ment. Sci., 101, 834 (1955).

71 Meduna, L. von, Gyoaszat., "76, 225 (1936).

72 Cerletti, N., and Bini, L., L'Elletroshock Arch. Gen. di Neurol. Psychiat.'Psicoanal., 91, 266 (1938).

\title{
OBITUARIES
}

\section{Mr. Harold Tongue, C.B.E.}

Harold Tongue died in St. Thomas's Hospital, Iondon, on February 18, after a long illness.

Educated at the Municipal Secondary School, Manchester, and the Manchester College of Technology, Tongue served his engineering apprenticeship jointly with Crossley Brothers, Ltd., and Kendall and Gent, Ltd. After Army service throughout the whole of the First World War, he joined the Cooperative Wholesale Society, Ltd., and eventually became chief engineer of the Research Department. In the early days of his career he followed the advice which, in later years, he gave frequently to young engineers, and gained experience by changing his job as opportunities arose. During this period he served with the British Portland Cement Research Association, the National Boiler and General Insurance Company, Ltd., the Chemical Engineering Department of the Chemical Research Laboratory (Department of Scientific and Industrial Research) and the London County Council.

At the beginning of 1945 he was seconded to the Department of Scientific and Industrial Research for work in Canada in the atomic energy field. First at Montreal, and later at Chalk River, Ontario, he took over the major engineering responsibility for the first high-power heavy-water moderated reactor to be built in that country. The subsequent great success of this venture owed much to his careful supervision.

While in Canada he joined in the early planning of the Atomic Energy Research Establishment, and in 1947 be went to Harwell as chief engineer to help realize what was to become one of the world's largest research establishments. His programme was large and diverse: in addition to establishing the equivalent of a small town on the Berkshire Downs, two research reactors, Gleep and Bepo, had to be designed, manufactured and built, and the Engineering Division had to provide strong supporting services to the scientific divisions. On the development side, special workshops were set up to solve the then novel problems of graphite machining, and for the casting of uranium rods, and their subsequent fabrication into fuel elements.

With the architects and engineers of the Ministry of Works he planned, for the first time in Great Britain, the novel services required to handle radio. active materials on a large scale. The best tribute to his vision is that these services, though extended, have not changed materially in basic design.

In those days a major problem was the handling of radioactive wastes, including waste disposal, decontamination, laundry services and transport of radioactive liquids, and a special branch of the Engineering Division was set up to handle these matters. Harold Tongue had the greatest regard for safety, and he personally led the importantnegotiations with the Thames Conservancy Board, the Metropolitan Water Board and the Ministry of Health, which resulted in agreement on the administrative and technical controls required for the safe disposal of radioactive effluent.

The Engineering Division included a large proportion of industrial employees, and it was natural that the chief engineer became responsible for the overall management of industrial labour, and chairman of the Joint Factory Committee. It was here that Tongue's strength of character and sense of justice brought respect from all concerned, and his philosophy on industrial management and human relations will live through his close associates, whom he influenced profoundly.

In 1950, after the Windscale plutonium-producing piles had been completed, there was a difficult choice whether to deploy available effort at Harwell on graphite-moderated gas-cooled reactors, or on the design and development of a fast reactor, for power production. Harold Tongue, giving great weight to safety considerations, and to the concept of steady development, believed that the gas-cooled system was the natural successor to Bepo and the Windscale 
piles. The feasibility study of a gas-cooled system undertaken in 1951 and 1952 by his engineers, under Goodlet and Moore, in collaboration with Messrs. Babcock and Wilcox, Ltd., and Parolle and Wessoe, Ltd., laid the foundation for the present nuclear power programme in Britain.

In 1954 Tongue gallantly accepted medical advice to retire prematurely, although this was a severe blow to himself and his associates. Before leaving, however, he was able to see mature the first craftsmen and engineers from the apprenticeship scheme he founded. For his many contributions to atomic energy he was made C.B.E. in 1953.

Upon retirement he remained an active consultant to the Atomic Energy Research Establishment at Harwell. Happily he lived to see the publication of the second edition of his first book, "Design and Construction of High Pressure Chemical Plant". He was also the author of "A Practical Manual of Chemical Engineering".

\section{P. BOWLES \\ R. H. Burns}

\section{Dr. D. T. Germain-Jones}

Dr. Donald Thomas Germain-Jones retired from the post of ehief geophysicist of the British Petroleum Company in August 1959 at the early age of fifty-two. He was having a well-earned rest before taking another assignment when he met his death by drowning after a boating accident on the Thames on January 20 . The news of the death of so young and active a man carne as a great shock to his friends and colleagues in the geophysical world.

Dr. Germain-Jones was born on November 24, 1906, and was educated at the University of London. $\mathrm{He}$ was a Royal Scholar of the Royal College of Science and obtained a first-class associateship and a first-class B.Sc. degree in 1926. In the following year he was awarded the diploma of the Imperial College, and in 1937 he obtained a Ph.D. degree for his work on Iranian geophysical problems. He was a Fellow of the Institute of Physics, of the Royal Astronomical Society and of the Institute of Petroleum. He was an early member of the Society of Exploration Creophysicists, and a founder, and later president, of the European Association of Exploration Geophysicists. He contributed greatly to the successful launching of the journal, Geophysical Prospecting, of the latter Association, and wrote a number of articles for the Journal of the Institute of Petroleum on developments in exploration geophysies.

'D.T.' began his long and distinguished career in geophysies when he joined BP (Anglo-Persian Oil Co. as it then was) in Iran in 1927. Those were early days in seismic exploration, and field-work consisted largely of in-line refraction surveys with a Mintrop seismo. graph. In the 1930's, new instruments and techniques for are shooting were evolved, which proved ideal for outlining rapidly the axes of the steeply folded structures such as Haft Kel, White Oil Springs and Gach Saran. In 1936, Dr. Germain-Jones discovered by these methods the Lali oilfield under a pronounced surface syncline; this achievement helped to establish the reputation within the Anglo.Persian Oil Co. of geophysics as a method of finding oil.

Dr. Germain-Jones was a leading figure in refraction work throughout this period. He established the fact that the producing Asmari limestone is a very poor carrier of refracted energy because of its limited thickness and that the refractor recorded in Iran was a much deeper Cretaceous (Rudist) limestone. He established methods of refraction interpretation by means of matching reversed in-line refraction shooting long before the publication of any papers on this subject.

His flair for organization and research led to the highly successful development of British Petroleum's first geophysical research station at Kirklington Hall, near Nottingham, and was later to aid him in the build-up of the Geophysical Division when he became chief geophysicist in 1953, at a time of great expansion of activities.

'D.T.' liked an outdoor life and sports. As a young man he was interested in swimming, walking and tennis, and when senior research geophysicist at Kirklington, he founded sports clubs for such pastimes as archery and rifle-shooting.

The untimely death of such an enthusiast will be a great loss to the oil exploration industry. Dr. Germain-Jones was truly a great pioneer.

$\mathrm{He}$ is survived by his wife and one daughter.

\section{NEWS and VIEWS}

\section{Pharmacology in Leeds : \\ Prof. D. R. Woods}

DR. D. R. Wood, who has been appointed to the chair of pharmacology in the University of Leeds in suceession to Prof. W. A. Bain (see Nature, 182, $1550 ; 1958)$, is a graduate of Oxford in medicine and science and had worked in Prof. J. H. Burn's department there. $\mathrm{He}$ went to Sheffield as lecturer in pharmacology in 1948 and was promoted senior lecturer in 1952. He has worked for short periods with Dr. B. N. Halpern in Paris and with Prof. Georg Kahlson in Lund. During the academic year 1955-56 he worked in the Department of Pharmacology at Yale University School of Medicine. In September 1957 he took up his present post as associate professor of pharmacology at McGill University. Dr. Wood's main interests have been in gastric secretion and in antihistamine drugs, but he has collaborated extensively with other workers par- ticularly in the biochemical field. In addition to his research and teaching duties, he served as secretary of the British Pharmacological Society during $1952-57$.

Education at Sheffield:

Prof. Boris Ford

Mr. Borrs Ford has been appointed director of the Institute of Education and professor of education in the Institute, University of Sheffield. Mr. Ford was educated at Gresham School, Holt, and the University of Cambridge, where he graduated with first-class honours in the English Tripos in 1939. Mr. Ford served in the Army during 1939-46, and from 1946 until 1951 was suecessively chief editor, deputy director and finally director of the Bureau of Current Affairs. In 1951 he was appointed information officer of the Technical Assistance Board of the United Nations, and during 1953-55 he was secretary of the national inquiry into liberalizing technical 